\title{
Sustainable Tourism Development in Rural Areas: The Role of Stakeholders
}

\author{
Marjetka Rangus \\ University of Maribor, Faculty of Tourism, Slovenia \\ marjetka.rangus@um.si \\ Boštjan Brumen \\ University of Maribor, Faculty of Tourism, Slovenia \\ bostjan.brumen@um.si \\ Jasna Potočnik Topler \\ University of Maribor, Faculty of Tourism, Slovenia \\ jasna.potocnik1@um.si
}

This article examines the role of local inhabitants in developing sustainable tourism in rural areas. Recently, when planning the sustainable local spatial, economic and social development, experts have been faced with the problem of integrating stakeholders. In the concept of sustainable regional development, the basic democratic premise that everyone should decide on matters that affect them has gained an equal position to that of environmental and social awareness. In compliance with this principle, the development of local communities which are also responsible for tourism development in a certain area should include the widest possible group of representatives of the local population. Lively tourist activities not only affect the economy, but also have impacts on the spatial development of the town, its social structure, social life, and psychological imprint. The analysis of the structured interviews conducted with more than 20 individuals who are employed in the fields of tourism in the wider area of Brežice has shown how the wider local community is responding to the tourist activities in the Municipality of Brežice and its surroundings.

Keywords: rural development, tourism, local inhabitants, attitude, Brežice https://doi.org/10.26493/2335-4194.10.167-173

\section{Introduction}

In recent decades, scientists and professionals in tourism have noted that tourism certainly cannot be narrowed down to an economic activity. Tourism is a complex phenomenon, which is heavily involved in the local, regional, national, and multinational environments and, as such, it also affects a variety of factors. In addition to the well-known positive effects, tourism development also brings negative ones. Interest in exploring the social, economic and environmental influences is, consequently, considerable, espe- cially when regarding the research of the effects of the tourism development in rural (and protected) areas, and exploring the relationship of the locals towards tourism. Although rural tourism is a valuable 'developmental strategy for destinations,' many challenges for its successful development have been identified, such as poor planning and implementation of rural tourism projects, poorly coordinated marketing efforts, seasonal profits and employment opportunities, lack of entrepreneurship, lack of government support, lack of collaboration, etc. (Farmaki, 2016, p. 283). Re- 
cently, studies on the attitudes of the local population towards tourists around the world and in Slovenia have been on the rise, and what is more, building sustainable communities has become one of the most important goals of governments and municipalities (Alonso \& Nyanjom, 2017). Stakeholder consultation has, in fact, become inevitable for sustainable tourism development (Hardy \& Pearson, 2017) since tourism monitoring is finally recognised as a stakeholder-driven process (Modica, 2016, 125), and destinations are perceived as networks of interdependent stakeholders (Waligo, Clarke, \& Hawkins, 2015). Bestard and Nadal $(2007,194-207)$ have reached the same conclusions. Due to the importance of tourism and its positive effects on the one hand, and the negative effects on the other, this fact is not surprising. Local inhabitants support the development of tourism if they believe that they will benefit from it (Allen, Hafer, Long, \& Perdue, 1993). Regarding the development of tourism in rural areas, additional care for the environment is necessary, as well as additional sensitivity in the protection of the resources needed, in an attempt to prevent too great a negative impact of tourism on the environment. There are no possibilities for sustainable tourism development without taking the opinions and the will of the local population into account. Chiun, Ramayah, and Hui (2014, 84-94) write about the primary importance of adopting tourism and supporting its development by different communities in the countryside. They state that for the sustainable tourism industry and the satisfaction of the local population, it is of great importance that local people are able and willing to participate in the development. Key to the successful development of tourism are the frequency of encounters between locals and tourists and willingness of the local people to be friendly hosts. Understanding stakeholders' characteristics and point of views can help predicting opposition or support for the development of tourism that may consequently be incorporated into tourism strategies (Phi, Dredge, \& Whitford, 2014; Hunter, 2013).

Tourism development can change the relationships between the population and the attitudes of the population towards their home environment. Huang and Stewart (1996) believe that the attitude and perception of the local population towards the effects of tourism is significant and that they should, therefore, be included in the programming strategies of tourism development and into all development strategies and programs, because it is only in that condition that the development of tourism can truly be successful. Furthermore, the findings showed that people who have the most of the financial benefits from the development of tourism are more supportive of the development of tourism (Harrill, 2004). Caves and Tanrisevdi state that the process of tourism development evokes negative emotions (anger, and resentment) with the local inhabitants, and consequently lower satisfaction of the local people. In contrast, the local inhabitants that are involved in the planning of tourism development develop positive attitudes. Nevertheless, the findings show that the majority of the local inhabitants understands the development of tourism as a tool for economic development and growth (Gursoy, Jurowski, \& Uysal, 2002).

Understanding the attitudes of the local population towards tourism is, therefore, very important, as is the integration of this understanding into plans of the development of sustainable tourism in a particular environment. Harrill (2004) states that the attitudes of the local population towards tourism affect three main reasons for tourism support: socioeconomic factor, spatial factor and economic dependence. Teye, Sirakaya, and Sönmez (2002) enumerate the following factors: the current relationship between tourists and residents, the importance of the tourism industry in the local community, economic dependency of the economy, the level of development of tourism in the area, the place of birth of each person, the duration of living of an inhabitant in the local community and, the distance between the place of residence of the inhabitant and the tourist center. Besculides, Lee, and McCormick (2002) state that the people with stronger ties with the local community are more concerned about the effects of tourism than those with weaker ties are. Smith and Kranninch (1998) demonstrate a direct link between the development of tourism and the emergence of negative attitudes among the local population, and Pearce (1980) argues that areas with highly developed tourism generate discontent of the 
local population because of the problems with parking, crime, rising prices, etc. (Bestard \& Nadal, 2007, p. 195). According to Mason and Cheyne (2000), due to increased traffic, noise, and crime, women support the development of tourism less than men do. Several studies have explored the relationship between locations/activities of tourism development and the attitudes of the population, based on the hypothesis that '[the] closer a resident lives to concentrations of tourism activity, the more negative his or her perception will be of tourism development' (Harrill, 2004). The results of various studies differ, which is affected by various factors, Harill (2004b), however, claims that the attitude of the population towards tourism largely depends on how much money tourists bring and how much of it stays in the local community. Besculides et al. (2002) note that the local inhabitants are concerned about the impact of tourism on the environment, but also grateful for the existence and development of the tourism industry, as long as tourism is an important source of economic development in the region (Bestard \& Nadal, 2007, p. 196).

Scientific research and literature in this area also show that the consideration of the opinions of local people is significant not only because of the better tourist services and facilities and increased revenue but also due to the more effective planning of the environment and nature conservation. New strategies not only take into account the opinions of residents, but they also promote their active involvement, which further contributes to the conservation of protected and endangered areas and the preservation of cultural heritage, which is a key reason for going to a tourist destination among many tourists (Farahani \& Musa, 2008, p. 1233; Szell, 2012, p. 26).

Furthermore, research carried out in Slovenia, show similar results. Ambrož (2008) states that the attitude towards space is obviously an important factor in defining the relationship of individuals to the development of tourism, and at the same time he confirms the theses of the above-mentioned research in the Slovenian environment (p. 75).

Therefore, sustainable tourism management is of utmost importance. The elements of sustainability and sustainable management are also emphasized in the tourism development strategies, i.e. in the Strategy of sustainable growth of the Slovenian tourism 2017-2021 (Ministrstvo za gospodarski razvoj in tehnologijo, 2017), in the Strategy of tourism of the Brežice Municipality 2017-2021 (Občina Brežice \& Fakulteta za turizem Univerze v Mariboru, 2016), as well as in the older tourism development strategies: Strategy of Development of Slovenian Tourism 2012-2016 (Vlada Republike Slovenije, 2012) and the Strategy of Development of the Tourist Destination of Posavje 20112015 (Regionalna razvojna agencija Posavje, 2011). In the of strategies, the equal participation of all stakeholders is modeled and educational actions to this end are prepared.

\section{Material and Methods}

The research questions of the presented article are how people in the rural area understand tourism and what the perception of tourism as a factor of local economic and societal development is.

The research was conducted in the Municipality of Brežice in 2015. The municipality lies in the southeastern part of Slovenia, in the Posavje Region, which is a typical rural area; it stretches over $268 \mathrm{~km}^{2}$ and is located along the rivers Krka and Sava. In size, Brežice is among the ten largest municipalities in Slovenia. Brežice is an economic, administrative, and cultural centre of the Brežice Plain and the surrounding hills. The central area of the municipality is the plain, while the northern and southern parts are hilly and, due to its position, the municipality is suitable for fruit and wine growing. The area has excellent natural conditions, which is a prerequisite for the development of tourism. A major railway and a road link Ljubljana, the capital of Slovenia, and Zagreb, the capital of Croatia. The town has some industry (furniture, metal industry), developed wholesale trade (wine), production and service trade, and transport. In Brežice, there is also a general hospital, which covers the needs of the Posavje Region and wider surroundings. The cultural landscape is rounded off by the Posavje Museum in the Brežice Castle and the Brežice Grammar School (secondary school). Brežice also represents the school centre of the Posavje Region. There are the general Grammar School, Secondary School of Economics 
and Secondary Commercial School, and the Faculty of Tourism of the University of Maribor. An interesting attraction is the water tower, which is visible from afar and is one of the two such preserved towers in Slovenia (Rra-posavje.si, 2017; slovenia.info, 2017; Komočar, 2009, p. 14).

Statistical indicators show that according to the number of tourist overnight stays and tourist arrivals, for years, Brežice has been among the most successful tourist resorts in Slovenia, but the largest share, more than 90 per cent in this is held by the spa center of Terme Čatež (Škerbinc, 2014, p. 15; Škerbinc, 2016, pp. 13-25).

Furthermore, in other parts of the municipality diverse tourist services and facilities are available, but the majority of tourist still concentrated in the spa centre of Terme Čatež. To also attract domestic and foreign guests in the old town centre of Brežice, in the old town many fairs and festivals, cultural and sporting events are held. The spa represents one of the biggest employers in the municipality and is expected to manage local tourism development and invest in the development of the municipality and preservation of the environment. In the field of tourism management, there is a public institute for tourism development, but it is also occupied with youth policy and entrepreneurship incentives. Thus, Terme Čatež is one of the key factors shaping and influencing the perception of tourism and tourists in the local environment.

In the Municipality of Brežice, 24 semi-structured interviews with 25 questions were conducted with individuals who were employed in the tourism sector or were themselves owners of tourism businesses. The interviewees were hand-picked and equally distributed all over the area of the Municipality of Brežice. Among the interviewees, there were representatives of large and small tourism businesses and various tourist attractions. Interviews were carried out by the students of the Faculty of Tourism of the University of Primorska to maximise open and honest dialogue between the interviewer and interviewees. The interviews were conducted by two students, with one of the students asking the questions and talking to the interviewee and the other recording the answers on a paper sheet. All technical instruments for record- ing were forbidden due to honesty and transparency reasons.

The questionnaire contained 26 short open questions on interviewees' positions towards the tourism development in the Brežice municipality.

The interviews were later transcribed, and codification was conducted. The first level of codification was conducted on an individual level by the students and the second was performed in the panel of students and researchers. On the first level, all the statements of positions were isolated as single positions and counted for each question. On the second level, the same statements were joined. On the third level, statements were carefully analysed by a panel of students; similar statements were joined into single positions. After the first analysis, another round of codification was conducted on the first level by an individual researcher and on the second and third levels by the panel of researchers. Further, results and interpretation of both rounds of analysis are presented.

\section{Results and Discussion}

On the first level, 749 single statements on positions towards tourism and tourists in Brežice were counted. After the second round of analysis, 290 single positions to answer specific questions were identified. The third level of analysis was possible only on seven questions. The research showed that statements could be clustered into four main clusters: positive and negative positions related to personal (individual) level, and positive and negative positions related to the state of the art on the community level. Furthermore, positions are clearly expressed as positive or negative in the relation towards tourism and tourists in the municipality. On the basis of this research, a model of positions was constructed as presented in Figure 1.

The general research shows that people understand tourism as a positive phenomenon, since they understand that it adds to the importance of the town and brings dynamics and events to the local community. Through tourists, they realise the beauty of their landscape and richness of local heritage and grow in pride and self-confidence.

The findings of the research both confirm some previous findings and show bipolarity of the attitudes 


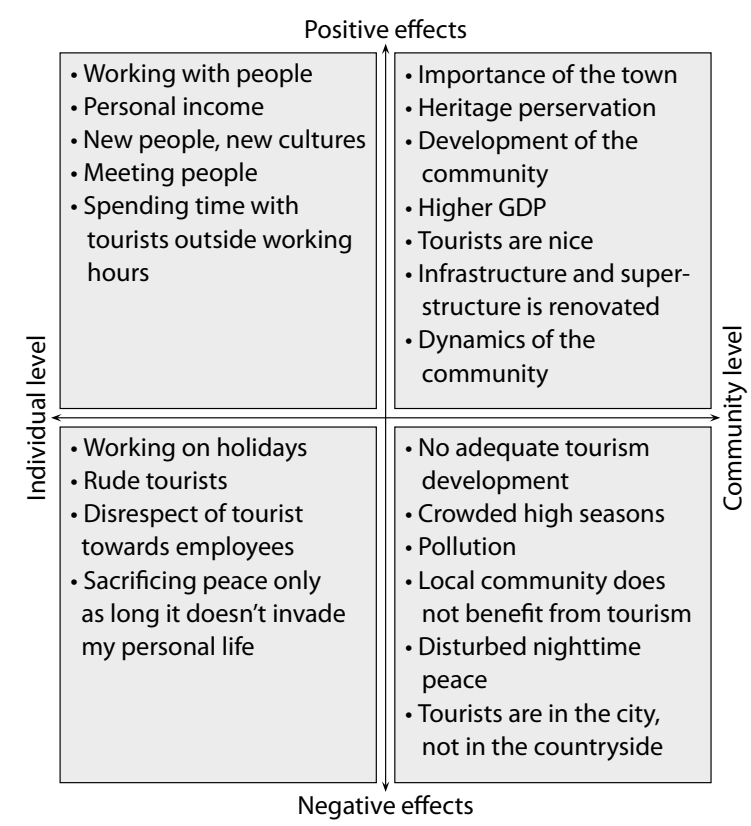

Figure 1 Model of Attitudes towards Tourism at Individual and Community Level

toward tourism and tourism development in the community. Similar to the Harrill (2004) findings, the research discussed in this paper has also shown that people who have the most of the financial benefits from the development of tourism are more supportive of the development of tourism. However, the distinction can be seen among those employed in the tourism businesses and small owners of tourism businesses. Those who are not owners of the businesses and only work in the tourism sector as employees are not ready to sacrifice their personal space and peace to support further tourism development.

The results of the research also support previous findings that show that the majority of the local inhabitants understands the development of tourism as a tool for economic development and growth. (Gursoy et al., 2002). However, the understanding of tourism as a part of everyday life differs on the individual and community levels. As presented in Figure 1, interviewees support the development of tourism as long as it does not invade their personal space, but they all support more tourist arrivals and further tourism development in every respect on the community level. On the community level, people support all the activities, festivals, sporting events and attractions but as long as the activities stay within the limits of to 10.00 p.m. to 6.00 a.m. nighttime peace rule. Interviewees indicate the need to be open to the tourists and let them into their lives, but do not want to socialise with them in their own free time. The majority of them speak with tourists strictly in the scope of their working duties, but at the same time, they admit that tourists usually want to learn how people live in the community and become acquainted with their everyday habits.

The vast majority of the interviewees expressed the need to improve the relationships with tourists to benefit from the tourism development, but they simultaneously do not believe this is possible in a short period nor do they see themselves as the initiators of any changes. They expect that the next generations will take the leading roles in this area, and support the bigger involvement of the local government institutions in the promotion of the area.

\section{Conclusion}

Today, tourism is widely recognised as a strong factor in rural area development. This recognition includes high expectations in the field of sustainability, green policy stakeholder participation. Residents and local businesses must be included in strategic planning and implementation of developing sustainable tourism. Evidence from this and other research show the need for mediation and strong cooperation among residents, all big and small tourism businesses and private and volunteer associations. There should be consensus on the kind of tourism to be developed in the community, and the responsibility for actions should be equally distributed.

The inhabitants of the Municipality of Brežice have positive relationship toward tourism, but they do not want it to invade too much into their personal lives. This is in a way contradictory to their observation in the interviews when stating that tourists want to find out how people live everyday life. They expect tourism will boost the development of the rural area in the future, and that local government and the biggest tourism businesses will take the leading roles and re- 
sponsibility for the tourism development in the community. The findings clearly indicate the need for active destination management and actions with regards to stakeholder education and involvement. Furthermore, more emphasis should be put on the quality of life of residents and in the processes of education and raising the sense of hospitality.

For more specific answers, further research is needed. This research was conducted only in private and partly in the civil sector, but not in the public sector, which is an important stakeholder in the local tourism development in rural areas. Local government and public institutions, also public health organisations, schools, sport and cultural organisations should be captured in the research in order to prepare some guidelines how to model the stakeholder participation in a rural area.

\section{References}

Allen L. R., Hafer H. R., Long R., \& Perdue R. R. (1993). Rural residents' attitudes toward recreation and tourism development. Journal of Travel Research, 31(4), 27-33.

Alonso, D. A., \& Nyanjom, J. (2017). Local stakeholders, role and tourism development. Current Issues in Tourism, 2o(5): 480-496.

Ambrož, M. (2008). Attitudes of local residents towards the development of tourism in Slovenia: The case of Primorska, Dolenjska, Gorenjska and Ljubljana Region. Anthropological Notebooks, 14(1), 63-79.

Besculides, A., Lee, M. E., \& McCormick, P. J. (2002). Resident's perceptions of the cultural benefits of tourism. Annals of Tourism Research, 29(2), 303-319.

Bestard, B. A., \& Nadal, J. R. (2007). Attitudes towards tourism and tourism congestion. Region et Developpement, 25, 193-207.

Caves, S., \& Tanrisevdi, A. 2003. Residents' attitudes toward tourism development: A case study in Kusadasi, Turkey. Tourism Analysis 7(3-4), 259-269.

Chiun, L., Ramayah, T., \& Hui, H. L. H. (2014). Rural communities perceptions and attitudes towards environment tourism development. Journal of Sustainable Development, $7(4), 179-197$.

Farahani, Z. H., \& Musa, G. (2008). Residents' attitudes and perception towards tourism development: A case study of Masooleh, Iran. Tourism Management, 29(6), 12331236.

Farmaki, A. (2016). Managing rural tourist experiences: Lessons from Cyprus. In M. Sotiriadis \& D. Gursoy
(Eds.), The handbook of managing and marketing tourism experiences 281-298. Bingley, England: Emerald.

Gursoy, D., Jurowski, C., \& Uysal, M. (2002). Resident attitudes: A structural modeling approach. Annals of Tourism Research, 29(1), 79-105.

Hardy, A., \& Pearson, J. L. (2017). Examining stakeholder group specificity: An innovative sustainable tourism approach. Journal of Destination Marketing \& Management. Advance online publication. doi:10.1016/j.jdmm .2017.05.001

Harrill, R. (2004). Residents' attitudes toward tourism development: A literature review with implications for tourism planning. Journal of Planning Literature, 18(3), 251-266.

Huang, Y., \& Stewart, W. P. (1996). Rural tourism development: Shifting basis of community solidarity. Journal of Travel Research, 36(4), 26-31.

Hunter, W. C. (2013). Understanding resident subjectivities toward tourism using Q method: Orchid Island, Taiwan. Journal of Susainable Tourism, 21, 331-354.

Komočar, M. (2009). Analiza razvoja turizma v občini Brežice. Maribor: Ekonomsko-poslovna fakulteta Univerze v Mariboru.

Mason, P., \& Cheyne, J. (200o). Residents' attitudes to proposed tourism development. Annals of Tourism Research, $27(2), 391-411$.

Ministrstvo za gospodarski razvoj in tehnologijo. (2017). Strategija trajnostne rasti slovenskega turizma 2017-2021: izvleček za razpravo na usklajevalnih delavnicah. $\mathrm{Re}-$ trieved from: http://www.mgrt.gov.si/fileadmin/mgrt .gov.si/pageuploads/STRATEGIJA-_Usklajevalne _delavnice_izvlecek.pdf.

Modica, P. (2016). Sustainable tourism management and monitoring: Destination, business and stakeholder perspectives. Milan, Italy: Franco Angeli.

Občina Brežice \& Fakulteta za turizem Univerze v Mariboru. (2016). Strategija turizma Občine Brežice 2017-2021. Retrieved from https://www.brezice.si/mma/-/ 2017020914471637/

Pearce, D. G. (1980). Tourism and regional development: A genetic approach. Annals of Tourism Research, 7(1), 6982.

Phi, G., Dredge, D., \& Whitford, M. (2014). Understanding conflicting perspectives in event planning and management using Q method. Tourism Management, 40, 406415 .

Regionalna razvojna agencija Posavje. (2011). Strategija razvoja turistične destinacije Posavje 2011-2015. Retrieved from http://www.rra-posavje.si/uploads/files/strategija 
_razvoja_turisti\%C4\%8Dne_destinacije_posavje_2011 -20151.pdf

Rra-posavje.si. (2017). O Posavju. Retrieved from http:// www.rra-posavje.si/o-posavju.html

Slovenia.info. (2017). Brežice. Retrieved from http://www .slovenia.info/si/Mesta-in-krajivSloveniji/Bre\% $\mathrm{C}_{5}$ \%BEice.htm?_ctg_kraji=2545\&lng=1

Smith, M., \& Krannich, R. (1998). Tourism dependence and resident attitudes. Annals of Tourism Research, 25(4), $783-801$.

Szell, A. B. (2012). Attitudes and perceptions of local residents and tourists toward the protected area of Retezat National Park, Romania (Unpublished Master's Theses). Western Michigan University, Kalamazoo, MI.

Škerbinc, S. (2014). Analiza turističnega prometa v letu 2013. Retrieved from http://www.tgzs.si/uploads/ANALIZA \%20TURISTICNEGA\%2oPROMETA\%20V\%2oLETU $\% 202013 . p d f$
Škerbinc, S. (2016). Analiza turističnega prometa v letu 2015. Retrieved from http://www.tgzs.si/uploads/ANALIZA \%20TURISTI\%C4\%8CNEGA\%2oPROMETA\%20V \%20LETU\%202015.pdf

Teye, V., Sirakaya, E., \& Sönmez, S. 2002. Resident's attitudes toward tourism development. Annals of Tourism Research, 29 (3): 668-688.

Vlada Republike Slovenije. (2012). Strategija razvoja slovenskega turizma 2012-2016. Retrieved from http://www.rra -posavje.si/uploads/files/strategija_razvoja _slovenskega_turizma_2012-2016_partnerstvo_za _trajnostni_razvoj_turizma_

Waligo, V., Clarke, J., \& Hawkins, R. (2015). Embedding stakeholders in sustainable tourism strategies. Annals of Tourism Research, 55, 90-93.

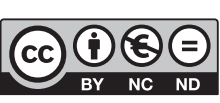

This paper is published under the terms of the Attribution- NonCommercial-NoDerivatives 4.0 International (CC BY-NC-ND 4.0) License. 